\title{
Knowledge Networks in Organic Fruit Production across Europe: A Survey Study
}

\author{
Eligio Malusà ${ }^{1, *(1)}$, Ewa M. Furmanczyk ${ }^{1}\left(\mathbb{D}\right.$, Małgorzata Tartanus ${ }^{1}\left(\mathbb{D}\right.$, Gerjan Brouwer $^{2}$, Claude-Eric Parveaud ${ }^{3}(\mathbb{D}$, \\ François Warlop ${ }^{3}{ }^{(0}$, Markus Kelderer ${ }^{4}$, Jutta Kienzle ${ }^{5}$, Evelyne Alcazar Marin ${ }^{6}$, Teun Dekker ${ }^{7}$, Radek Vávra ${ }^{8}{ }^{(0}$, \\ Vincenzo Verrastro ${ }^{9} \mathbb{D}$, Hanne Lindhard Pedersen ${ }^{10}$, Clémence Boutry ${ }^{11}$, Michael Friedli ${ }^{11}$ and Marco Schlüter ${ }^{12}$
}

check for

updates

Citation: Malusà, E.; Furmanczyk,

E.M.; Tartanus, M.; Brouwer, G.;

Parveaud, C.-E.; Warlop, F.; Kelderer, M.; Kienzle, J.; Alcazar Marin, E.; Dekker, T.; et al. Knowledge Networks in Organic Fruit Production across Europe: A Survey Study. Sustainability 2022, 14, 2960. https://doi.org/10.3390/su14052960

Academic Editors: Simone Belli and Chia-Lin Chang

Received: 29 December 2021

Accepted: 28 February 2022

Published: 3 March 2022

Publisher's Note: MDPI stays neutral with regard to jurisdictional claims in published maps and institutional affiliations.

Copyright: (C) 2022 by the authors. Licensee MDPI, Basel, Switzerland. This article is an open access article distributed under the terms and conditions of the Creative Commons Attribution (CC BY) license (https:// creativecommons.org/licenses/by/ $4.0 /)$.
1 The National Institute of Horticultural Research, 96-100 Skierniewice, Poland; ewa.furmanczyk@inhort.pl (E.M.F.); malgorzata.tartanus@inhort.pl (M.T.)

2 Delphy B.V., 6700 CA Wageningen, The Netherlands; g.brouwer@delphy.nl

3 Groupe de Recherche en Agriculture Biologique, 84911 Avignon, France; claudeeric.parveaud@grab.fr (C.-E.P.); francois.warlop@grab.fr (F.W.)

4 Centro di Sperimentazione Laimburg, 39040 Auer, Italy; markus.kelderer@laimburg.it

5 Fordergemeinschaft Okologischer Obstbau EV, 74189 Weinsberg, Germany; jutta@jutta-kienzle.de

6 Asociación ECOVALIA, 41013 Sevilla, Spain; ecovalia.projects@ecovalia.org

7 Sveriges Lantbruksuniversitet, 75007 Upssala, Sweden; teun.dekker@slu.se

8 Vyzkumny a Slechtitelsky Ustav Ovocnarsky Holovousy s.r.o., 50801 Holovousy, Czech Republic; radek.vavra@vsuo.cz

9 Centro Internazionale di Alti Studi Agronomici Mediterranei, 70010 Valenzano, Italy; verrastro@iamb.it

10 HortiAdvice, 5250 Odense, Denmark; hlp@hortiadvice.dk

11 Forschungsinstitut für Biologischen Landbau FiBL, 5070 Frick, Switzerland; clemence.boutry@fibl.org (C.B.); michael.friedli@fibl.org (M.F.)

12 Naturland-Verband für ökologischen Landbau e.V., 82166 Gräfelfing, Germany; m.schlueter@naturland.de

* Correspondence: eligio.malusa@inhort.p1

\begin{abstract}
Limited data regarding the resources and methods used by organic fruit growers to learn about production practices are available, even though this information is crucial to improving the efficacy of knowledge transfer. Therefore, a survey to gain information from knowledge networks dealing with organic fruit production about their structural organisation, tasks and methods of communication was carried out in twenty-one countries from Europe and the Mediterranean basin. A total of 56 networks representing about 42,500 professionals were identified as a result of the survey. The vast majority of them were only active at the regional or national level and were composed of farmers, advisors and researchers. About $3 / 4$ of the networks were developing improved strategies for agronomic practices and about half of them were also involved in different knowledge-transfer activities between their members. Personal contact was the most used method to exchange and disseminate information within the networks as well as to elaborate improved strategies. The findings were analysed in view of the methods and practices commonly used to share both explicit (scientific) and implicit (practical) knowledge among practitioners. It was concluded that knowledge networks play an important role in the development of more resilient organic cropping systems, frequently making organic fruit growers the drivers of innovation. Networking for knowledge exchange was considered a process that encourages the active involvement of farmers in experimentation and innovation applying a method of knowledge sharing that is rooted in the very foundation of organic philosophy. Some recommendations and future research were suggested to further foster the development and functioning of networks for knowledge exchange.
\end{abstract}

Keywords: pome fruits; stone fruits; citrus; informal knowledge

\section{Introduction}

The European market demand for organic products recorded in 2019 a growth rate of $8 \%$, almost doubling in the last decade, to reach a value of retail sales of about EUR 
41.4 billion [1]. This situation is paralleled by EU policy promoting the expansion of organic production: it should achieve $25 \%$ of the total agricultural production by 2030 in order to comply with both Green Deal and Farm to Fork strategies, thus supporting the targets set by the Sustainable Development Scenario (SDS) goals [2]. Even though the EU is the leading region for the production of organic fruits in the world with 1.6 million hectares, and the land dedicated to organic temperate fruit production reached about 121 thousand hectares, which covers about $13 \%$ of organic production [1], to achieve these targets, the organic fruit growers need to increase their supply and, more critically, the number of organic producers in the EU needs to increase at a faster rate. However, switching from conventional to organic production systems is a challenging path, since organic farming, particularly for perennial crops like fruit crops, is knowledge-intensive and technically demanding. Therefore, to support organic farmers during the conversion phase or in improving yields of organic fruit systems it is necessary to foster knowledge sharing [3-5]. The transfer of knowledge to learn and implement organic management practices should happen through accessible information sources.

Technical scientific knowledge, i.e., codified (explicit) knowledge documented by scientific or technical documents, and applied knowledge, i.e., tacit (implicit) knowledge based on personal experience (know-how or expertise) acquired through practice and experience [6] are crucial to ensure successful management of organic cropping systems [7,8]. However, even though the flow of information among researchers, advisors and farmers is intended to be a dynamic and interactive process, the information transfer usually follows a top-down process, which is not effective in the new context of sustainability [9]. Nevertheless, in some cases and countries, e.g., Germany, the Netherlands or northern Italy, knowledge transfer has been successfully applied among professionals involved in organic production.

To overcome these bottlenecks and improve knowledge transfer, linking research with practice, particularly in the area of sustainable agriculture and organic farming, has become the key feature in both the scientific environment and official rural and research policies. Efforts are being made in this direction by dedicated programmes such as the European Innovation Partnership for agricultural productivity and sustainability. Indeed, these new tools aimed at overcoming the bottlenecks for getting research results are adopted on the ground because of insufficient information flow and missing links between the different actors of the Agricultural Knowledge and Innovation Systems (AKIS) [10]. Moreover, multiactor approaches, co-design of experimental approaches, direct applicability of research findings, and partnership between research and practitioners are considered necessary to ensure adoption of innovations, particularly in the area of sustainable management, and are required to obtain research funding. It has been shown that knowledge-intensive agricultural practices, such as plant protection or plant nutrition under organic farming, benefit from new methods of knowledge exchange, particularly by learning through mutual interaction and shared understandings rather than classic dissemination or knowledgetransfer activities [11]. Therefore, the role of knowledge networks in this regard has been considered critical to fostering the adoption of innovative practices.

Different types of knowledge networks have been described, including "formal networks", formed by different stakeholders but mainly including research or advisory institutions exchanging primarily codified knowledge, or "informal networks", composed primarily by farmers benefiting from the exchange of primarily tacit knowledge. The former type would be the base of the Agricultural Knowledge System (AKS), while the latter is part of the Agricultural Knowledge and Information System (AKIS) [9,12-14].

Flexible, dynamic collaborative networks where joint learning shapes innovation have been named in the literature on rural studies as public-private partnerships [15], or networks of practice [16]. Of particular interest for the organic fruit sector are the Learning and Innovation Networks for Sustainable Agriculture (LINSAs), which are hybrid networks bringing together producers, customers, NGOs, researchers, experts and actors of the formal AKS (i.e., ministries, research institutes, extension services) [17]. Indeed, LINSAs 
emphasise the processes generating learning and innovation through interactions between the involved actors and making this useful and applicable to other actors [18]. Another example of collaborative networks is represented by the "European Network of Living Labs" (https: / / enoll.org, accessed on 28 December 2021), an international non-profit association established in 2006, which promotes user-driven innovation ecosystems integrating research and innovation processes in real-life communities. According to the IN-SIGHT project study [19], innovation starts with actors and evolves through hybrid networks, as it has been demonstrated for innovation in rural tourism [20] or in novel forms of direct relations between producers and consumers typical of organic farming, such as internet selling and solidarity purchasing groups [21]. Informal farmers' knowledge exchange and learning have been analysed under different contexts and agricultural systems [22,23], including organic farming systems [24,25], always showing that this method has a considerable potential to promote the adoption of sustainable practices typical of organic production.

There are limited data regarding the resources and methods used by organic fruit growers to learn about production practices. This information, however, is crucial in order to improve the efficacy of knowledge transfer to serve the organic fruit sector. Indeed, the collective construction of knowledge and innovation in organic agriculture is still quite unexplored [26]. To this aim, a survey was carried out in the framework of an EUfunded project (BIOFRUITNET https: / / biofruitnet.eu/, accessed on 28 December 2021) to identify knowledge networks present in Europe and neighbouring countries and analyse the types of information transfer. In particular, information was collected about the methods used by organic fruit farmers to share information, the information sources used and the structure of their knowledge networks. This was considered the necessary starting point to contribute to the key features of Organic 3.0, for a continuous improvement of organic fruit growing towards best practices, using the modern tools of communication and dissemination used by the networks to increase the share of tacit knowledge of farmers and farm communities [27]. The paper presents the results of this survey, particularly focusing on the organisation of the networks, their scope and tasks, their communication methods and funding sources. The discussion is highlighting the features and aspects that should be taken into consideration in developing policies and activities to improve the technical level of organic fruit farmers.

\section{Materials and Methods}

A survey to gain information about the presence and structural organisation of knowledge networks dealing with organic fruit production was carried out in twenty-one countries from Europe (seventeen EU member states, Switzerland and Norway) and the Mediterranean basin (Turkey and Morocco). The survey was conducted from November 2019 to March 2020. This methodology was followed to fulfil the theoretical background for such studies as defined by Pinsonneault and Kraemer [28], i.e., defining the survey as a means for gathering information about the characteristics, actions, or opinions of a large group of people (i.e., the knowledge networks), and by Salant and Dillman [29], who underlined that the surveys can assess needs, evaluate demand, and examine the impact.

Qualitative and quantitative methods were employed for the study based on the Grounded Theory [30], applying a constructivist approach [31], which conceptualises the actors' knowledge as context-specific [32]. Therefore, in order to standardise the selection of relevant networks, the network was defined as "a group composed by one or more kinds of stakeholders (e.g., farmers, advisors, researchers, etc.) that are exchanging information on a regular basis about issues related to organic fruit production, either formally or informally". The validity of the definition was tested by conducting verification of understanding its meaning on a group of stakeholders (advisors and researchers) among the institutions that were participating in the project activities. The approach underlined by the definition was thus meant to favour "grass-root" networks, more likely classifiable as LINSAs or similar categories, that would focus on the exchange of practice knowledge, as the BIOFRUITNET projects aim to focus on this aspect. 
Each selected network was requested to provide information following a questionnaire during semi-structured interviews carried out in local language, with data about the organisation of the network, its activities and other kinds of information related to technical knowledge (in total fourteen topics, see questionnaire form in Supplementary Material). The majority of the questions proposed multiple-choice answers, to favour a standardised approach by respondents, while few allowed customised answers. The focus of the survey was not only related to the way informal knowledge is exploited or organised, but also about how the networks are developed, organised, structured and financed. This was assumed to give a broader understanding of their functioning and how policies could further foster network development.

The collected data were analysed statistically, calculating frequencies and categorising the answers on the basis of the different classes identified in the questionnaire.

\section{Results and Discussion}

\subsection{Territorial Distribution of the Knowledge Networks}

A total of 56 networks representing about 42,500 professionals were identified that fulfiled the specific definition (Figure 1). The networks included thus some big and wellstructured organisations (e.g., FÖKO e.v. in Germany, Ecovalia in Spain, FNAB in France, Agrobio in Portugal) as well as smaller networks (e.g., Polski Ekoowoc in Poland, Prisma in Netherland, Jonicabio in Italy). Forty-five per cent of the analysed networks were present in only three countries: France (10 networks; $18 \%)$, Spain $(8 ; 14 \%)$ and Italy $(6 ; 11 \%)$. In most countries, only one network was present (9 countries out of $20 ; 45 \%$ ). Even though the total number of existing networks in practice could be higher than the number of identified networks, due to informal networks being difficult to identify, this outcome fully reflected the level of development and rate of organic fruit production in the different countries. According to the most recent statistics, the three countries mentioned above with the most networks identified also have the largest share of area for permanent crops grown organically. These three countries total about 1.3 million ha of organic permanent crops, with about $21 \%$ dedicated only to temperate fruits and citrus, whereby France and Italy are leading in the production area of temperate fruits, and Italy and Spain in that of citrus crops [1]. Nevertheless, it should also be pointed out that in the same cases, like Germany and Austria, the few networks are very well organised and active, also gathering a relevant number of members.

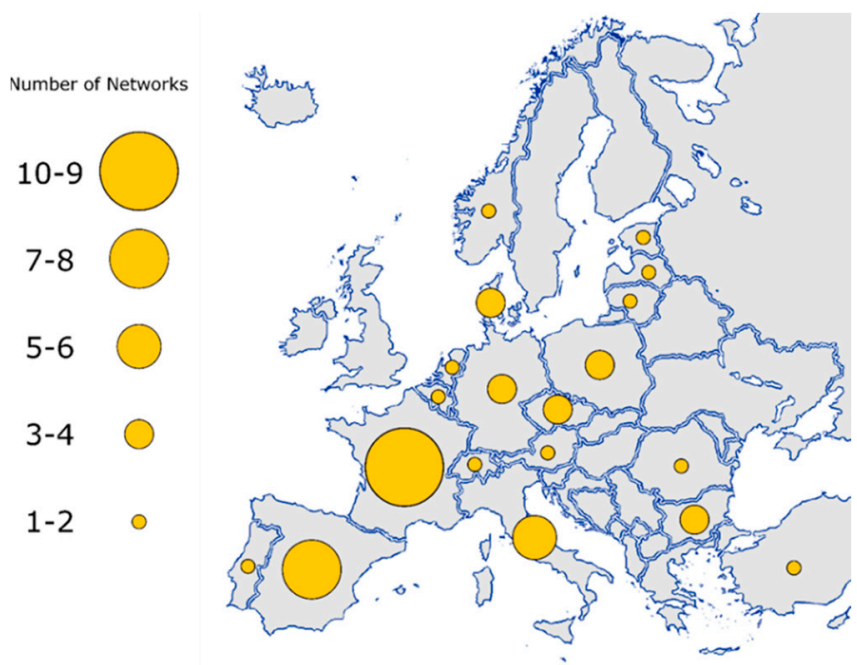

Figure 1. Distribution of the knowledge networks (see text for definition) of organic fruit production across Europe. The number of networks does not reflect the networks' complexity, size (number of members) or tasks performed. 


\subsection{Knowledge Networks' Structure and Composition}

The majority of the networks (50 out of 56) were formed by institutions or organisations belonging to one single sector of stakeholders: i.e., private sector (e.g., farmers (20 networks)), public (e.g., research institutions (16)), and non-governmental organisations (9) or other organisations (e.g., informal groups or interprofessional associations (5)). The remaining networks included representatives of two or three sectors (Table 1). Unquestionably, the private organisations had the most important share in the analysed networks, as they were present in $41 \%$ of the networks. The detailed analysis of the professional stakeholders participating in the networks pointed out that the majority of members were farmers, advisors and researchers (Figure 2A). Farmers were present as members in almost $86 \%$ of the networks, followed by advisors (68\%), and researchers (59\%). Marketing organisations and consumers were involved in about $23 \%$ of the networks while certifying bodies or breeders were declared to be members of about $11 \%$ of them.

Table 1. Analysis of the membership structure of the knowledge networks according to the sector of members' activity.

\begin{tabular}{cc}
\hline Network Membership Structure & Percentage (\%) \\
\hline Single sector & \\
Public & 28.6 \\
Private & 35.7 \\
NGO & 16.1 \\
Other ${ }^{1}$ & 8.9 \\
Two sectors & 3.6 \\
Public + Private & 1.8 \\
Public + NGO & 3.8 \\
NGO + Other & \\
Three sectors & 1.8 \\
Private + NGO + Other &
\end{tabular}

${ }^{1}$ Includes informal groups or interprofessional associations.

A

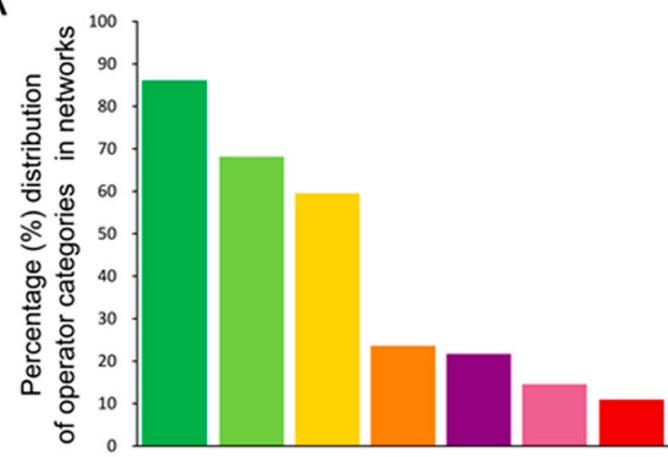

Farmers

Advisors

Researchers

Marketing Organisations

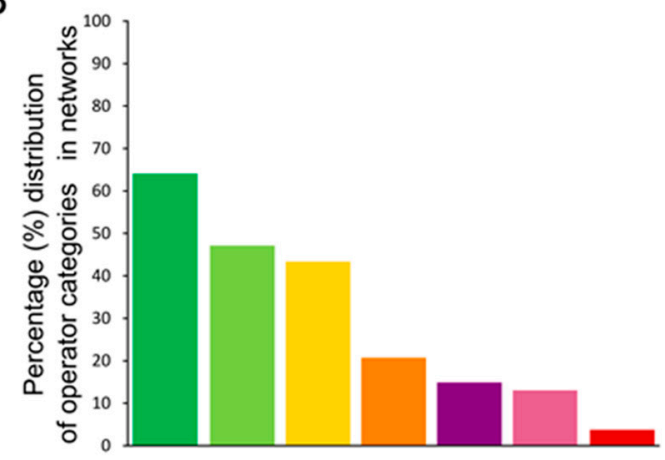

Figure 2. Participation level of each category of operators as members (A) or in management (B) of knowledge networks.

Analogously to the membership, farmers were the most represented group of stakeholders in the networks' management structure (Figure 2B). However, about $63 \%$ of them were comprised, singly or together, of professionals dealing with research or advisory. Frequently, these institutions were the body that established the network. Very few networks included breeders (13\%), but, interestingly, some of them also have among their members certifying bodies (around $4 \%$ ) or marketing organisations, which shows the link between the production and the regulatory issues typical of organic farming. Even 
more intriguingly, eight networks included in their management staff from associations or representatives of public authorities or consumer bodies. However, the latter networks can be considered as the most complex and advanced structures. Indeed, networks with members belonging to more than four different groups of stakeholders were the minority compared to those including up to four stakeholder groups, which accounted for more than $88 \%$ of the networks (Figure 3 ).

A

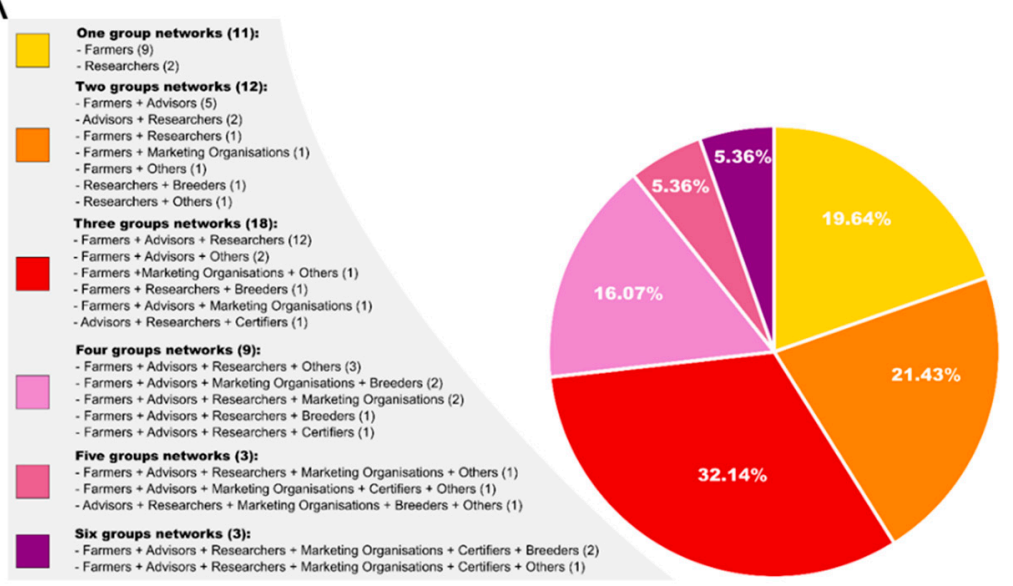

B

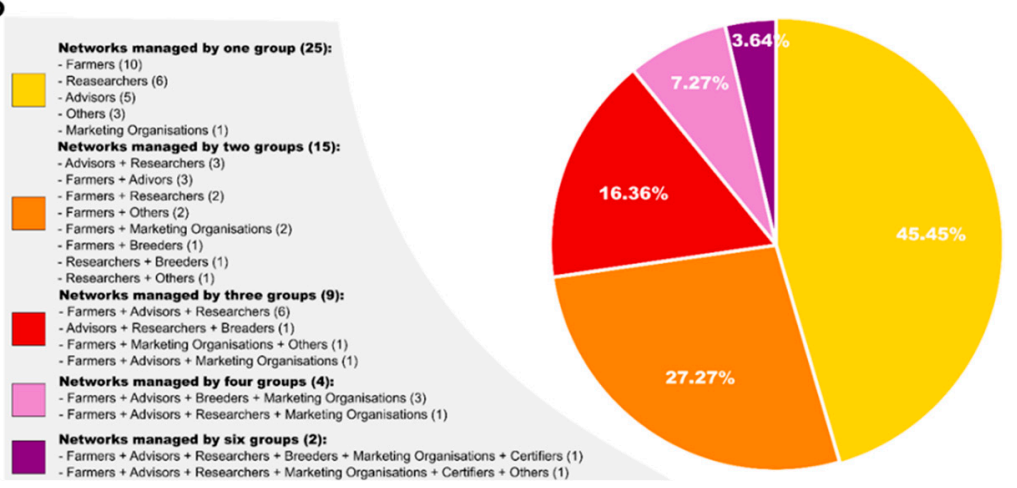

Figure 3. The complexity of the members' structure (A) or management structure (B) of the surveyed networks. The detailed structure of the networks is listed next to the chart. Numbers in brackets represent the number of networks with identified structures.

The responses of the surveyed networks showed that the vast majority of them were active only at the national $(42.9 \%)$ or only at the regional level $(30.4 \%)$, with a limited number active at both levels (10.7\%). However, this result also depended on the country, as in some cases the regional level was more frequent, particularly with small-sized networks. Moreover, only a few of them $(1.8 \%)$ were functioning only at the international level, while networks active at multi-levels reached $16 \%$ of the share.

Networks composed mainly by practitioners rely mainly on the exchange of so-called tacit knowledge and can be related to the "communities or networks of practice" [16]. These kinds of networks are highly dependent on "social capital", which is based on "sharing values and understandings that facilitate cooperation within or among groups" [14], and their knowledge is considered useful for practical topics. These practitioners' networks are of particular importance since learning and knowledge creation, especially in the case of sustainable practices such as organic farming, has occurred often through informal, rather than formal, mechanisms [6]. Such an approach was also attributed to the high degree of uncertainty and changes in organic production conditions due to policies, prices, technologies, climate, and quality demands that require rapid adaptation [33] that can be better addressed through farmers' networks [16,25]. 
It has been argued that farmers' knowledge is often derived from different sources and, in the case of external sources, the knowledge needs to be adapted, verifying its applicability, by the farmer to foster its adoption on a larger scale [34]. The quite relevant presence of advisors in the analysed networks could allow us to challenge previous findings pointing to a limited contribution of this group of stakeholders, particularly of private advisors, on knowledge transfer to farmers $[35,36]$. Indeed, a survey aiming at deciphering the technical needs and knowledge gaps carried out within the BIOFRUITNET project (unpublished data) showed that direct exchange between farmers and advisors was the most frequent method used for technical know-how transfer, encouraging thus advisors to play the role of facilitators in knowledge transfer [37]. Interestingly, previous studies highlighted that for the area of planting material and breeding, the main relevant stakeholders in knowledge exchange of innovative best practices were other farmers, farmers' associations and publicly funded researchers, while public advisors were not part of those networks [38]. The high technical knowledge required by organic fruit production is an aspect that could have increased the role and presence of advisors in the currently analysed networks, which confirms other examples of the successful impact of advisors in improving organic farming practices $[25,39]$. A similar view could be applied to the presence of research institutions in the networks as they can be seen not only as a source of knowledge but also as promoters of networks through bridging activities [40]. The complementarity of farmer knowledge and formal scientific knowledge resulted to achieve the best results [41-43], particularly when decentralised and participatory research was promoted [44].

The high proportion of networks made of several stakeholders found in our survey, which were mainly present in countries with a tradition and high share of organic fruit production (e.g., Germany, France and Italy), confirms recent research findings underlining that multi-actor knowledge networks are more successful in developing and implementing sustainable practices $[9,45,46]$. Such a multi-actor approach has also been fostered at the European level by the EU Commission in research programmes and by the European Innovation Partnership "Agricultural Productivity and Sustainability" (EIP Agri) initiative, focusing on the integration of actors from various backgrounds to combine knowledge sources [47]. Multi-actor networks have also been fostered at the national level (e.g., "Groupe 30,000" in Ecophyto programme in France) and local level (e.g., EU-funded "Leader" programmes).

The territorial level, at which networks were found to be more active, reflects the assumptions that they may more easily arise through communities of practice. These can lead to innovation in production techniques within specific socio-environmental conditions, typical of a determined territory [48]. An important barrier for the enlargement of these locally limited networks can derive from the language barrier. In this regard, a leading example of overcoming the language barrier is the informal network at the base of the Ecofruit conference (https: / / www.ecofruit.net/, accessed on 28 December 2021). It started gathering German-speaking advisors, researchers and farmers involved mainly in organic apple production, and only later developed into an international forum with contributions from all over the EU on all organic temperate fruits. Digital resources can become a key tool to overcome the language barrier [49]. Online multilingual platforms, such as the Organic Farm Knowledge platform (https: / / organic-farmknowledge.org/, accessed on 28 December 2021), can provide access to high-quality and trusted digital learning resources on organic agriculture to farmers from different countries [50]. Exploiting internet-based translation services (e.g., Google Translator or DeepL) can also help, though the technical vocabulary can be more difficult to be correctly translated automatically. However, the general opinion is that digital media could not replace but only complement face-to-face knowledge exchange, which still remains fundamental [50].

\subsection{Aims and Tasks of Networks Related to Knowledge Exchange}

Considering the activities performed by the networks (Figure 4), about 3/4 of the networks were involved in tasks aiming at improved strategies for agronomic practices. 
Moreover, about half of the networks included among their tasks different supporting activities to their members, the most frequent being advisory activities for marketing, fruit processing, farm trials, and lobbying at various levels, particularly concerning plant protection products. The integration of tasks within the networks' activity can be appraised considering that about 39\% were participating in all three task categories (dissemination, elaboration, others) and 29\% combined dissemination and elaboration activities (Figure 4A).

A

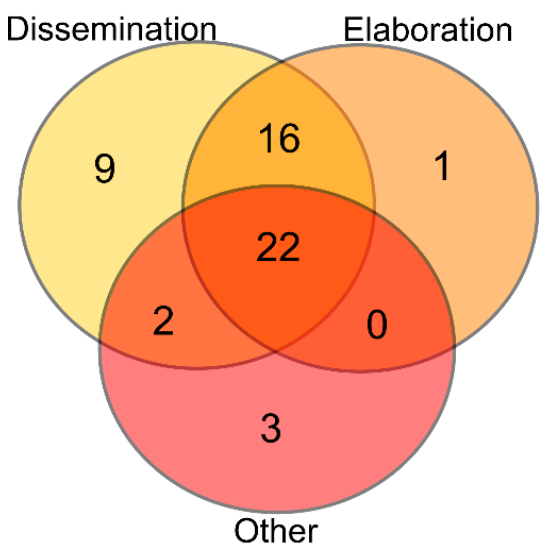

B

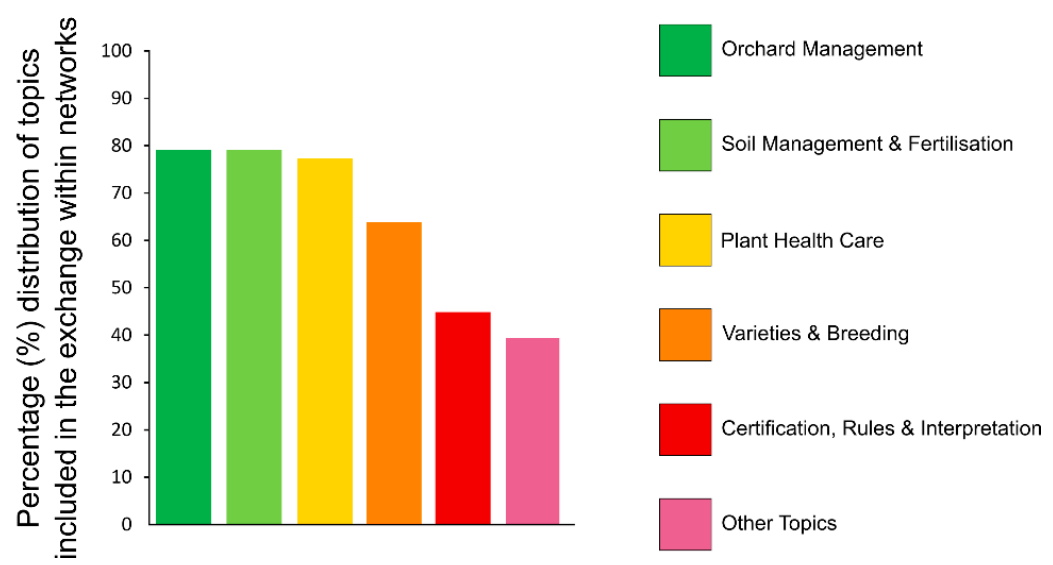

Figure 4. The tasks performed by the knowledge-transfer networks. (A) Venn diagram with the proportions and interactions of three different kinds of activities performed. (B) Frequency of different topics concerned with the exchange of technical knowledge within the networks.

Scientific knowledge and applied knowledge based on personal experience are critical for the successful management of organic cropping systems [7,8]. Nevertheless, organic growers often use several sources of information to adapt the proposed practices into their farming context according to their own experience [51]. The survey showed that the elaboration of strategies is a major task within networks, thus confirming these findings.

When analysing in detail the topics dealing with knowledge transfer of technical aspects, the three predominant fields of information tackled by the networks were orchard management, plant protection and soil management and fertilisation, with similar intensity (around $80 \%$ ) (Figure 4B). This was an expected result, since these are the major agronomical concerns in organic production, and are complex topics that require wide knowledge. Moreover, about $64 \%$ of networks were dealing with the subject of variety/rootstocks and breeding, which is an important aspect related to both plant protection and marketing. Certification and "other subjects" (e.g., market issues and sales channels, post-harvest, orchard biodiversity) were subjects worked on by a considerably lower number of networks ( $45 \%$ and $40 \%$, respectively). It is noteworthy that these "other subjects" were not always supported formally by the networks, thus pointing out that the need for knowledge about these topics is fulfiled by extemporary activities. Furthermore, it has been underlined that networks can be useful vehicles for knowledge transfer in new areas such as biodiversity management, climate change mitigation or quality certification $[52,53]$, which have been emerging in recent years with regard to broad environment management. Interestingly, specialised working groups within the networks were established only in about half the networks, generally, those managed by research institutions or in networks active at national and international level (e.g., the institute of organic agriculture-FiBL or the Moroccan Interprofessional Federation of the Organic Sector-FIMABIO or the GermanFOEKO), while seldom present in other kinds of networks (i.e., those referring to advisory bodies). Such outcome underlines once more the relevance of the local context in knowledge networking, even though it was shown that traditional networks (built, for example, around 
farmers' associations and auction markets) could be overcome by other networks triggered by more specialist interests [54].

\subsection{Networks' Communication and Knowledge Exchange Methods}

Personal contact was by far the most common way of exchanging and disseminating information within the networks (Figure 5). This is confirmed by the network's popular use of farm visits, public field days, conference participation, network conference meetings, internal group meetings and collective information visits. The majority of the networks $(66 \%)$ offered at least four different ways of personal communication. On the other hand, paper or electronic means of information transfer, which are also employed by networks, but at a lower level, seemed to only complement and strengthen the direct personal contact. Seldomly used means of communication, grouped as "Others", include the use of mobile messenger networks and the attendance of specialised fairs and exhibitions. Only eight networks (15\%) used all three kinds of communication methods mentioned in the questionnaire (personal, publishing materials, others), although more than $2 / 3$ of analysed networks implement two different ways of communication (usually personal contact and disseminations using paper or electronic publications).

A

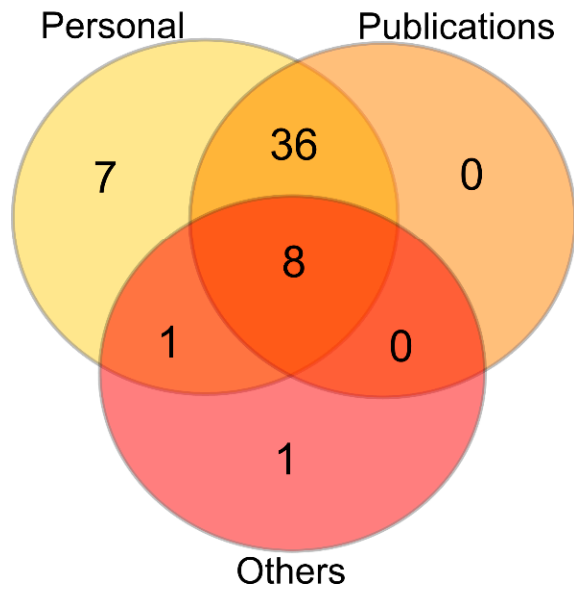

B

\begin{tabular}{lc}
\hline Method of Communication & $\begin{array}{c}\text { Percentage (\%) } \\
\text { of networks }\end{array}$ \\
\hline Personal & 98.1 \\
\hline Group Meetings & 79.3 \\
Conference / Meetings & 73.6 \\
Participation in Conference & 64.2 \\
Public Field Day & 58.5 \\
Farm Visit & 83.0 \\
Organisation of Collective Visits to Other Regions & 37.7 \\
\hline Publishing materials & 83.0 \\
\hline Newsletter & 39.6 \\
Internal Journal of Group & 22.6 \\
Publication on Website & 71.7 \\
Publication in Journal Outside Group & 35.9 \\
Scientific Publications & 35.9 \\
\hline Other & 18.9 \\
\hline
\end{tabular}

Figure 5. Methods of communications used by the networks for knowledge transfer. (A) Venn diagram of the proportions and interactions between ways of communication within the analysed networks. (B) The share of communication methods used by networks; the group "Others" includes mobile messenger networks, attendance of specialised fairs and exhibitions.

Direct knowledge sharing and exchange not only helps to develop and disseminate practices, but also strengthens the social structures of the network particularly when joint learning creates collective benefits, such as an improved local environment, an eradicated pest or a boosted local economy [43]. Results of a study carried out in the US [55] showed that networking, organisations, universities and books were among the most frequently mentioned sources used by organic growers. Networking had a significantly higher frequency of mention than online, certifiers and consultant sources of knowledge, and discussion with other farmers was identified as the "most effective" source of information [55]. Personal relationships were also key in information transfer for private forest landowners using sustainable and alternative practices [56].

Even though utilising forms of online communications can offer the opportunity to bridge spatial and/or perspective gaps [57], currently, the knowledge base across the EU on organic farming, specifically on organic fruit production, is still fragmented, even though the Organic ePrints platform (https:/ / www.orgprints.org/, accessed on 28 December 2021) forms a good source of knowledge. It is likely that an EU-wide platform providing technical 
information for organic fruit growers in multiple languages and formats, similar to that created for arable crops (OK-Net Arable [50]) and on organic feed for monogastric animals (OK-Net EcoFeed) could be extremely useful. However, to ensure efficient use of such a platform, it is important to consider that according to a large survey only about $30 \%$ of organic farmers considered the internet to be an important source of information [58], with time being the most significant barrier. The survey highlighted that the proportion of users of these sources was higher among young ( $<40$ years old) farmers and suggested that the increasing use of smartphones could extend the time periods during which farmers can access the internet to look up technical information. Interestingly, another study [59] found that even though $89 \%$ of farmers in southwest England used the internet for business management, only $9 \%$ used internet discussion boards and $6 \%$ used internet blogs. Moreover, when asked about the three sources they trusted most in terms of the knowledge imparted, advisors and other farming professionals (52\%), the farming press (36\%), business professionals (31\%) and farming friends (29\%) were the most cited [59]. Nevertheless, considering that organic farmers are generally younger than conventional farmers, with the share of organic farm managers under 40 years of age (21\%) being twice that of non-organic farms (10.5\%) [60], it can be assumed that they are more willing to use internet resources [61]. This fact points out the need of promoting organised platforms where researchers and practitioners could exchange information, also benefiting from the activity of innovation brokers [15]. The platform GECO (https://geco.ecophytopic.fr, accessed on 28 December 2021) is an example of such a collaborative platform set up in France, including a database of knowledge and a forum for discussion.

In line with the preferred methods of communication, it also emerged that the most used way of elaborating agronomical strategies related to the major practices of orchard management is through personal relations and participation in meetings and workshops where the results of the experiences gathered (also through trials) are discussed, divulgated and communicated (Figure 6). In this specific task of the network aiming at enhancing knowledge exchange and innovation, a major involvement of advisory or research stations in the organisation of meetings and workshops was observed: these were used by more than $60 \%$ of the participating networks. However, a more formal method to deliver elaborated strategies through different kinds of documents was also quite common, being used by more than $40 \%$ of the networks. It is noteworthy that only $1 / 3$ of the networks retain their results internally, generally those based on private stakeholders. Few networks (about 13\%), used more structured methods (e.g., conferences, training courses or even mobile messenger applications-all grouped in the "others" category) to discuss and elaborate innovative strategies. Farmer participation in technology development and participatory extension and research approaches are considered to enable novel technologies and practices to be learned and adapted to particular agroecological, social and economic circumstances [62]. The role of advisory and scientific institutions in organising events that promote the transfer of knowledge by targeting face-to-face networking (e.g., through regional meetings) can facilitate social gatherings focusing on a particular production challenge or opportunity and, according to our findings, can increase the efficacy of these activities. However, since the effectiveness of these providers in disseminating appropriate knowledge across farmer groups has been questioned, in addition to the limited knowledge about organic farming specificities [4], the use of new tools for communication (videos, role-games, etc.) should be highly recommended.

It is noteworthy that the topics covered by the networks were similar irrespective of the fruit crop group they were focused on, i.e., pome fruits, stone fruits and citruses. In addition, the economic importance of these three main fruit crop categories was reflected by the number of networks per fruit crop category. The majority of the surveyed networks (around 85\%) dealt with pome fruit production (Figure 7A), including apple and pear, followed by about $73 \%$ of the networks dealing with stone fruits (cherry, plum, apricot, peach and nectarines and almonds), though never as a single fruit species. As expected, citrus fruits (orange, lemon and other minor citrus crops) were dealt with by networks only 
of Southern EU and Mediterranean countries and accounted for 1/3 of the total number of networks interviewed, but only a few (4) were specialised only in citrus crops. The majority of the networks ( $>50 \%$ ) focused on two categories of fruit crops, often pome and stone fruits (Figure 7B), and only a handful of them (about $4 \%$ ) were focused on all fruit crops. Apart from pome fruits, where apple is greatly surpassing pear and other pome species in importance, networks dealing with stone or citrus fruits were not specialised in a singular crop species, with the different crops of the category sharing a quite similar level of interest (Figure 7C).

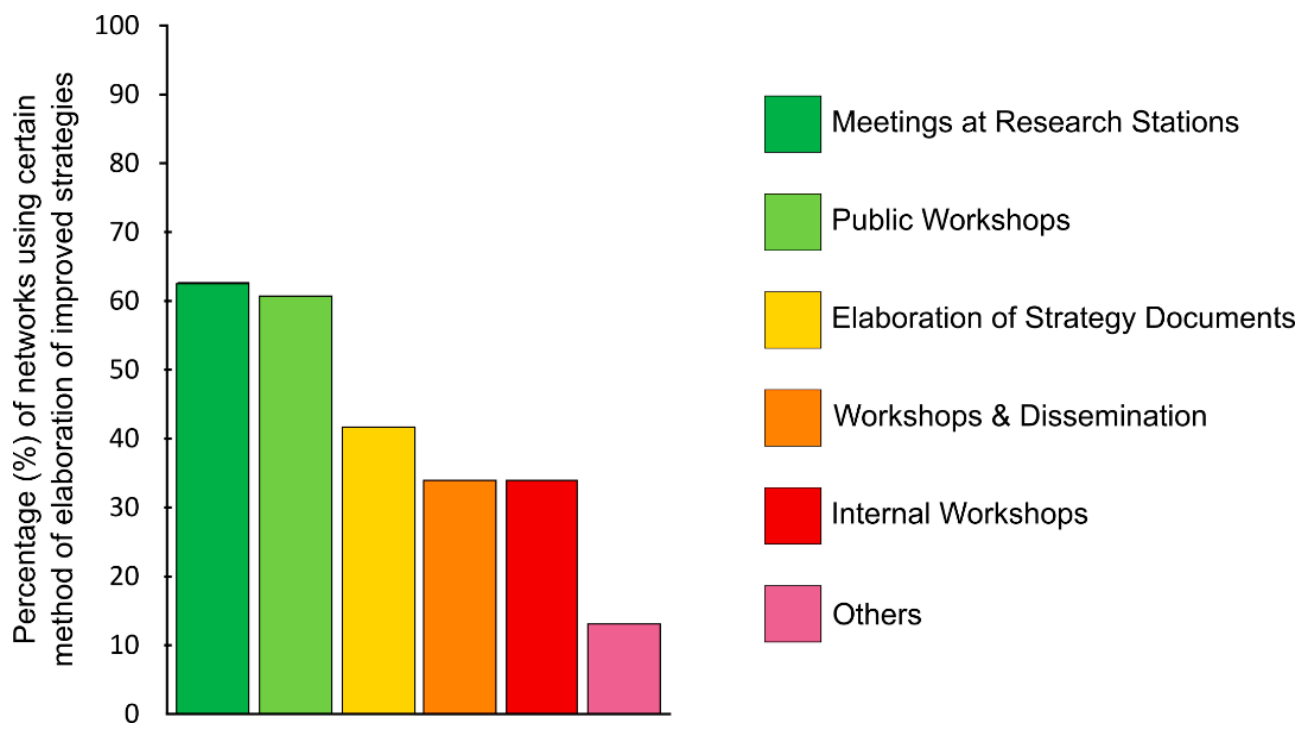

Figure 6. Relevance of the methods used for the elaboration of improved agronomical strategies utilised by knowledge networks.

Regarding the combination of fruit crops, as it could be expected considering the crops pedo-climatic requirements, twenty-one networks (40\%) dealt with both pome and stone fruits, while only two dealt with stone and citrus fruits (less than $4 \%$ ), and none with pome and citrus fruits. Besides the interest in the three main fruit crop categories, about $13 \%$ of the networks were also interested in other crops such as berries, olives, figs, hazelnuts and, in the case of the citrus-growing networks, in other minor citrus species, confirming the interest in a broad diversity of crops in organic fruit farms. Interestingly, one network from Romania was mainly dedicated to sea buckthorn, a minor berry species that is gaining interest in organic fruit production.

\subsection{Networks' Funding Sources}

According to the questionnaires, up to four different funding sources were utilised by networks (Figure 8A). However, most networks used only one or two funding sources (42-45\%, respectively), while a minority of networks used three (around 11\%) or four funding sources (less than $2 \%$ ). In addition, the survey showed that the share of public (external) funding and internal sources was in the same order of magnitude: $64 \%$ of networks declared to exploit public project funding and almost $57 \%$ of them mentioned members' fees as a source (Figure $8 \mathrm{~B}$ ). Institutional funding to either research or advisory institutions was utilised by almost $38 \%$ of networks, underlining the importance of these stakeholders in the network functioning. However, it is noteworthy that $15 \%$ of networks declared to work either on a voluntary basis, without any funding, or through other means of funding including private sponsors, and the network's offering of commercial services (all classified in the "Other" category). 
A

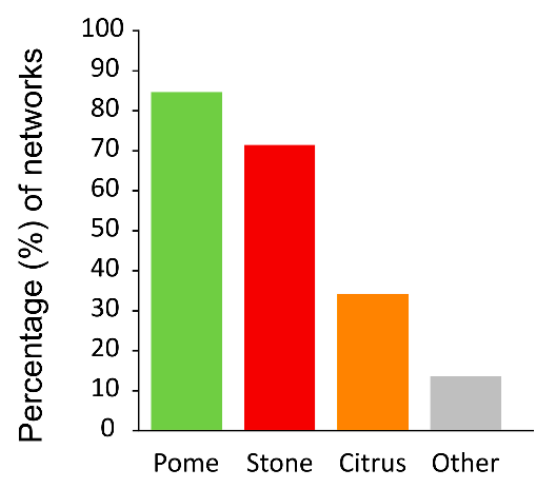

B

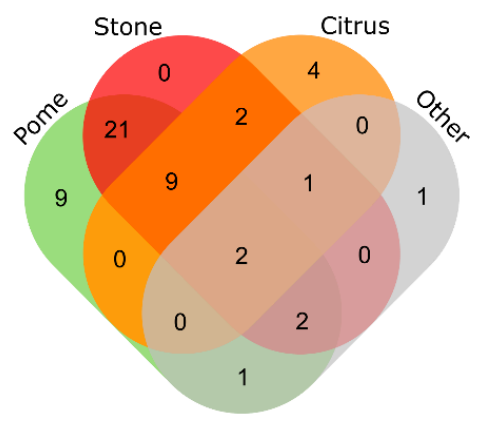

Citrus fruits

Other fruits

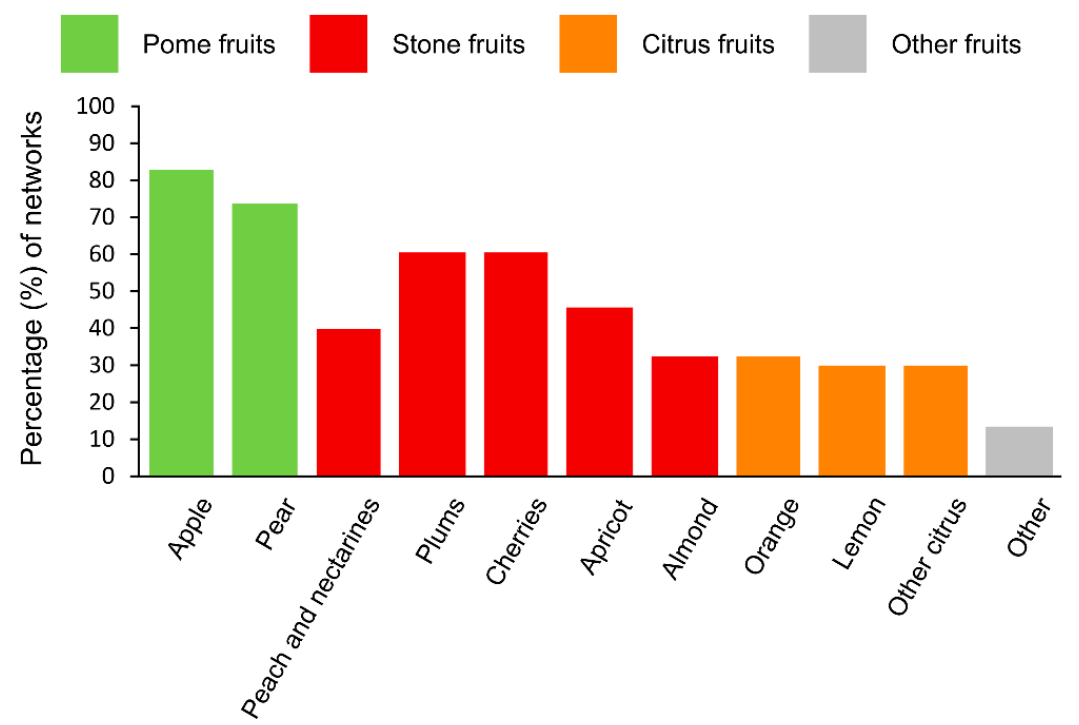

Figure 7. The fruit crop groups covered by networks. (A) The percentage of networks dealing with each fruit group. (B) Venn diagram showing the frequency of networks dealing with different combinations of fruit crop groups. (C) The percentage of networks dealing with specific fruit crops.

Informal networks have generally limited own resources, thus they constantly seek external support, mainly from public sources (either national or international), even though using public money can imply administrative or political burden. Currently, the search for funding should be eased by the fact that major funders (either at the national or EU level) are requesting a multi-actor approach in agricultural research, with the active involvement of all parties normally present in networks (i.e., farmers, advisors, manufacturers, consumers and the respective associations) from the very beginning, i.e., in co-designing project activities and goals. Such an approach is meant to implement the concept of the AKIS system, where farmers contribute to developing novelties as the outcome of different ways of thinking and doing things and in recombining different pieces of knowledge in an innovative way [10].

However, it has been underlined that there is little structural incentive for researchers or institutions to become engaged in participatory research because this part of their work is not considered a valuable research output $[38,63]$. Moreover, several studies have also highlighted the disconnection between agricultural advisory services, particularly private ones, and scientific research (e.g., $[35,64,65])$. Nevertheless, some well-established networks in organic fruit growing have managed to master this issue (e.g., in Germany, northern Italy, France). An effort to overcome these bottlenecks and also provide funding for long-term trials or studies (e.g., inbreeding) could derive from a change in the mechanisms of funding, 
particularly at the national level (e.g., using the resources of the Rural Development Plans), which are those most likely to be accessed by small networks.
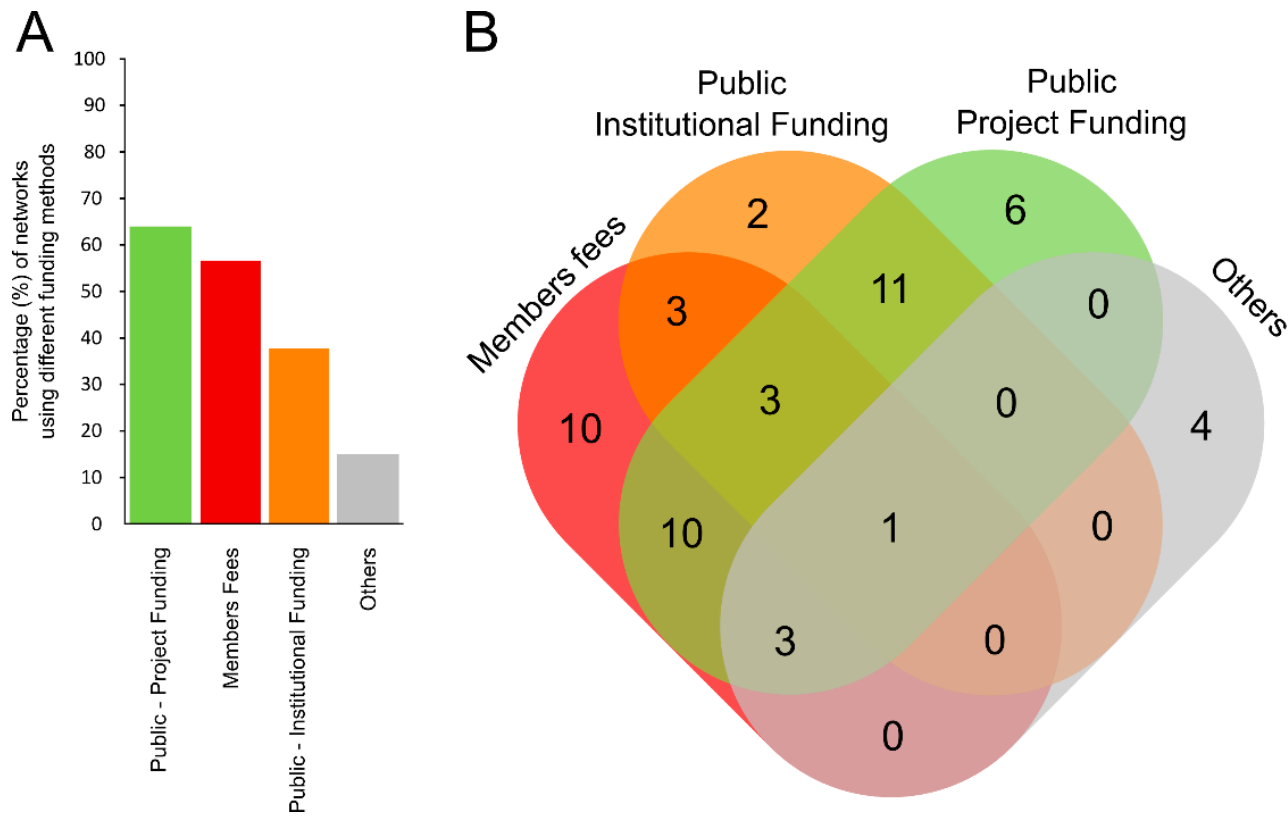

Figure 8. Sources of funding used by the knowledge networks. (A) The share of funding source. (B) Venn diagram showing the proportions between funding sources. "Others" includes no funding, private sponsors and the network's offering of commercial services.

\section{Conclusions}

Organic agriculture is expected to promote a shift in the paradigm of farming, contributing to solving challenges in the food chain, minimising environmental and food pollution and at the same time supporting fairness for producers and efficiency in resource utilisation [27]. This shift is particularly necessary in the case of organic fruit production. Indeed, organic fruit production systems currently have the risk of a "conventionalisation" of the management methods that are not fully in line with the basic principles of organic farming [66], showing reduced biodiversity by intensive mono-cropping [67] and with soil fertility and plant protection depending largely on external inputs [68]. Considering that both local (experience-based) and scientific knowledge are important for achieving sustainability in agricultural systems and that advisors can function as facilitators/catalysers of knowledge exchange, it is believed that knowledge networks involving all the actors can be an efficient method to move forward to match current demand from the society and the objectives set by EU policies for farming systems which can mimic nature increasing the on-farm biodiversity and the provision of eco-services [69]. The existing knowledge networks play an important role in the development of more resilient systems in a bottomup approach. This has been demonstrated in the case of resistant varieties where organic fruit growers have been the drivers of innovation. However, especially under the pressure of a rapid extension of organic production, they cannot meet the challenges they have to face just with their own resources. Therefore, knowledge networks that implement in-person interactions and exploit digital tools should be fostered in the organic production sector [70], specifically in organic fruit production, and accordingly supported with the necessary resources. These resources could include policies and incentives enhancing cooperation and the networks' human capital which can overcome technological, social, economic and cultural divides, factors that have been recognised as hampering knowledge networks' development [71].

Our results confirm the opinion that among organic farmers, networking knowledge is seen as a process that triggers interactive learning, encouraging the active involvement 
of farmers in experimentation and innovation, from and with other farmers often linked by a common philosophy and the commitment of making sustainable change happen [25]. The knowledge network approach could be seen as a method of knowledge sharing that gets to the very foundation of organic philosophy, considering the four core principles of organic farming set by IFOAM (health, care, ecology and fairness; [72]). Indeed, it has been underlined that farmers seeking a more sustainable production system, as the organic fruit farmers, have been found to rely more on alternative support, learning networks and knowledge sources rather than on the formal agricultural knowledge and innovation system. The latter is still strongly focused on the conventional, productionoriented model of agriculture that does not adequately address the knowledge needs of this type of farmer [43]. Nevertheless, quite unique when compared to other world regions, a body of specialised advisors in organic farming has been built in different countries of the EU, also as a result of the policies promoting organic farming. The wide presence in the networks of both advisory and research institutions found in our survey suggests that organic fruit farmers also rely on their knowledge and capacity of identifying needs and provide solutions worthy of adoption.

A key issue for the networks' development would lie in the level of interaction with other networks. Even though the territorial context has been underlined as a common feature of knowledge networks, with international interactions based mainly on the linguistic background or common projects, it is believed that networks with more connections at a higher territorial level may be better suited to confront critical issues and access new knowledge and innovations. In this respect, IFOAM EU could function as a network booster for its organic institutions' members. The effort of projects such as BIOFRUITNET is thus expected to favour an improvement of organic fruit knowledge networks. Indeed, the dynamic contexts and complexity of the agri-food system, with the specificities of organic fruit production, together with the current challenges facing agriculture require to fully recognise the value of knowledge networks in supporting a holistic pathway towards a resilient development that explicitly interlinks all three sustainability pillars (environmental, social and economic dimensions).

Some recommendations could be put forward as an overall conclusion stemming from the analysis performed. Knowledge networks should strive to widen their territorial dimension, particularly interacting with networks of regions characterised by similar climatic and cropping conditions. This effort could broaden the technical knowledge, but also allow to experience different approaches in orchard management or marketing strategies, paving the way tone technical innovations or business opportunities. A recommendation to policy-makers and local authorities would be to create policies supporting networks development or their activities in the long term. These could include exploring novel schemes of network functioning as well as non-conventional activities, e.g., gathering knowledge from networks dealing with other (non-agricultural) production sectors. These opportunities could foster a multi-actor approach to the organic fruit production value chain, creating synergies among the networks and their members. The methods best suited for the implementation of these recommendations should be a subject of future research.

Supplementary Materials: The following supporting information can be downloaded at: https:/ / www.mdpi.com/article/10.3390/su14052960/s1, Survey questionnaire.

Author Contributions: Conceptualisation and methodology, all authors; formal analysis and data curation, E.M. and E.M.F.; writing — original draft preparation, E.M.; writing — review and editing, all authors. All authors have read and agreed to the published version of the manuscript.

Funding: This research and APC were funded from the European Union's Horizon 2020 Research and Innovation Programme under Grant Agreement No 862850.

Institutional Review Board Statement: Not applicable.

Informed Consent Statement: Not applicable. 
Data Availability Statement: The data presented in this study are available on request from the corresponding author or the BIOFRUITNET consortium (https:/ / biofruitnet.eu/, accessed on 28 December 2021). The data are not publicly available due to the confidentiality level.

Conflicts of Interest: The authors declare no conflict of interest. The funders had no role in the design of the study; in the collection, analyses, or interpretation of data; in the writing of the manuscript, or in the decision to publish the results.

\section{References}

1. Trávníček, J.; Willer, H.; Schaack, A. Organic Farming and Market Development in Europe and the European Union. In The World of Organic Agriculture Statistics and Emerging Trends 2021; Research Institute of Organic Agriculture FiBL, Frick, and IFOAM-Organics International: Bonn, Germany, 2021; pp. 229-266.

2. European Commission. Communication from the Commission to the European Parliament, the Council, the European Economic and Social Committee and the Committee of the Regions: A Farm to Fork Strategy for a Fair, Healthy and EnvironmentallyFriendly Food System. COM2020381 Final 2020. Available online: https:/ / eur-lex.europa.eu/legal-content/EN/TXT/?uri= CELEX\%3A52020DC0381 (accessed on 28 December 2021).

3. Midmore, P.; Padel, S.; McCalman, H.; Isherwood, J.; Fowler, S.; Lampkin, N. Attitudes towards Conversion to Organic Production Systems: A Study of Farmers in England; Institute of Rural Studies the University of Wales: Aberystwyth, UK, 2001.

4. Lohr, L.; Park, T.A. Choice of Insect Management Portfolios by Organic Farmers: Lessons and Comparative Analysis. Ecol. Econ. 2002, 43, 87-99. [CrossRef]

5. Torres, A.P.; Marshall, M.I. Identifying Drivers of Organic Decertification: An Analysis of Fruit and Vegetable Farmers. HortScience 2018, 53, 504-510. [CrossRef]

6. Curry, N.; Kirwan, J. The Role of Tacit Knowledge in Developing Networks for Sustainable Agriculture. Sociol. Rural. 2014, 54, 341-361. [CrossRef]

7. Eshuis, J.; Stuiver, M. Learning in Context Through Conflict and Alignment: Farmers and Scientists in Search of Sustainable Agriculture. Agric. Hum. Values 2005, 22, 137-148. [CrossRef]

8. Nerbonne, J.; Lentz, R. Rooted in Grass: Challenging Patterns of Knowledge Exchange as a Means of Fostering Social Change in a Southeast Minnesota Farm Community. Agric. Hum. Values 2003, 20, 65-78. [CrossRef]

9. Knickel, K.; Brunori, G.; Rand, S.; Proost, J. Towards a Better Conceptual Framework for Innovation Processes in Agriculture and Rural Development: From Linear Models to Systemic Approaches. J. Agric. Educ. Ext. 2009, 15, 131-146. [CrossRef]

10. EU SCAR. Agricultural Knowledge and Innovation Systems in Transition-A Reflection Paper; European Commission: Brussels, Belgium, 2012.

11. Morgan, K.; Murdoch, J. Organic vs. Conventional Agriculture: Knowledge, Power and Innovation in the Food Chain. Geoforum 2000, 31, 159-173. [CrossRef]

12. Leeuwis, C.; van den Ban, A.W. Communication for Rural Innovation: Rethinking Agricultural Extension, 3rd ed.; Blackwell Science: Oxford, UK, 2004.

13. Hall, A. Public-Private Sector Partnerships in an Agricultural System of Innovation: Concepts and Challenges. Int. J. Technol. Manag. Sustain. Dev. 2006, 5, 3-20. [CrossRef]

14. OECD. The Well-Being of Nations: The Role of Human and Social Capital; Centre for Educational Research and Innovation: Paris, France, 2001. [CrossRef]

15. Klerkx, L.; Leeuwis, C. Matching Demand and Supply in the Agricultural Knowledge Infrastructure: Experiences with Innovation Intermediaries. Food Policy 2008, 33, 260-276. [CrossRef]

16. Oreszczyn, S.; Lane, A.; Carr, S. The Role of Networks of Practice and Webs of Influencers on Farmers' Engagement with and Learning about Agricultural Innovations. J. Rural Stud. 2010, 26, 404-417. [CrossRef]

17. Augustyn, A.; Nemes, G. Engaging Researchers with Learning and Innovation Networks for Sustainable Agriculture (LINSAs). Farming Syst. Facing Glob. Chall. Capacit. Strateg. 2014, 478-486. Available online: https://www.academia.edu/17 690126/Engaging_researchers_with_Learning_and_Innovation_Networks_for_Sustainable_Agriculture_LINSAs (accessed on 28 December 2021).

18. Rudman, C. Agricultural Knowledge Systems in Transition: Towards a More Effective and Efficient Support of Learning and Innovation Networks for Sustainable Agriculture (SOLINSA). Project Description. 2010. Available online: http://www.solinsa. org/the-project/the-project/ (accessed on 28 December 2021).

19. Tisenkopfs, T.; Brunori, G.; Knickel, K.; Sumane, S. Co-Production of Rural Innovation: Towards an Enriched Theoretical Model. In Innovation Processes in Agriculture and Rural Development. Results of a Cross-National Analysis of the Situation in Seven Countries, Research Gaps and Recommendations; Knickel, K., Tisenkopfs, T., Peter, S., Eds.; 2009; pp. 129-159. Available online: https://ub.unibas.ch/digi/a125/sachdok/2012/BAU_1_5998000.pdf (accessed on 28 December 2021).

20. Rantanen, M.; Granberg, L. Innovation Systems and Processes in the Field of New Rural Services: A Cross-National Analysis of Differences in Finland, Germany, Latvia and the Netherlands. In IN-SIGHT: Strengthening Innovation Processes for Growth and Development; Ruralia Institute, University of Helsinki: Helsinki, Finland, 2008. 
21. Brunori, G.; Rossi, A.; Guidi, F. On the New Social Relations around and beyond Food. Analysing Consumers' Role and Action in Gruppi Di Acquisto Solidale (Solidarity Purchasing Groups). Sociol. Rural. 2012, 52, 1-30. [CrossRef]

22. Beckford, C.; Barker, D. The Role and Value of Local Knowledge in Jamaican Agriculture: Adaptation and Change in Small-Scale Farming. Geogr. J. 2007, 173, 118-128. [CrossRef]

23. Goven, J.; Morris, C.M. Regulating Biopharming: The Prism of Farmer Knowledge. Sci. Cult. 2012, 21, 497-527. [CrossRef]

24. Blanc, J. Family Farmers and Major Retail Chains in the Brazilian Organic Sector: Assessing New Development Pathways. A Case Study in a Peri-Urban District of São Paulo. J. Rural Stud. 2009, 25, 322-332. [CrossRef]

25. Kroma, M.M. Organic Farmer Networks: Facilitating Learning and Innovation for Sustainable Agriculture. J. Sustain. Agric. 2006, 28, 5-28. [CrossRef]

26. Lamine, C.; Bellon, S. Conversion to Organic Farming: A Multidimensional Research Object at the Crossroads of Agricultural and Social Sciences. A Review. Agron. Sustain. Dev. 2009, 29, 97-112. [CrossRef]

27. Arbenz, M.; Gould, D.; Stopes, C. ORGANIC 3.0-the Vision of the Global Organic Movement and the Need for Scientific Support. Org. Agric. 2017, 7, 199-207. [CrossRef]

28. Pinsonneault, A.; Kraemer, K. Survey Research Methodology in Management Information Systems: An Assessment. J. Manag. Inf. Syst. 1993, 10, 75-105. [CrossRef]

29. Salant, P.; Dillman, D.A. How to Conduct Your Own Survey; John Wiley and Sons: Hoboken, NJ, USA, 1994; ISBN 978-0-471-01273-3.

30. Glaser, B.G.; Strauss, A.L. The Discovery of Grounded Theory: Strategies for Qualitative Research; Aldine de Gruyter: New York, NY, USA, 1967; ISBN 978-0-202-30260-7.

31. Schwandt, T.A. Constructivist, Interpretativist Approaches to Human Enquiry. In The landscape of Qualitative Research: Theories and Issues; Sage Publications: Thousand Oaks, CA, USA, 1998; pp. 221-259.

32. Raymond, C.M.; Fazey, I.; Reed, M.S.; Stringer, L.C.; Robinson, G.M.; Evely, A.C. Integrating Local and Scientific Knowledge for Environmental Management. J. Environ. Manag. 2010, 91, 1766-1777. [CrossRef]

33. Darnhofer, I.; Bellon, S.; Dedieu, B.; Milestad, R. Adaptiveness to Enhance the Sustainability of Farming Systems. A Review. Agron. Sustain. Dev. 2010, 30, 545-555. [CrossRef]

34. Stuiver, M.; Leeuwis, C.; van der Ploeg, J.D. The Power of Experience: Farmers' Knowledge and Sustainable Innovations in Agriculture; Van Gorcum: Assen, The Netherlands, 2004.

35. Labarthe, P.; Laurent, C. Privatization of Agricultural Extension Services in the EU: Towards a Lack of Adequate Knowledge for Small-Scale Farms? Food Policy 2013, 38, 240-252. [CrossRef]

36. Sutherland, L.-A.; Madureira, L.; Dirimanova, V.; Bogusz, M.; Kania, J.; Vinohradnik, K.; Creaney, R.; Duckett, D.; Koehnen, T.; Knierim, A. New Knowledge Networks of Small-Scale Farmers in Europe's Periphery. Land Use Policy 2017, 63, 428-439. [CrossRef]

37. Österle, N.; Koutsouris, A.; Livieratos, Y.; Kabourakis, E. Extension for Organic Agriculture: A Comparative Study between Baden-Württemberg, Germany and Crete, Greece. J. Agric. Educ. Ext. 2016, 22, 345-362. [CrossRef]

38. Ortolani, L.; Bocci, R.; Bàrberi, P.; Howlett, S.; Chable, V. Changes in Knowledge Management Strategies Can Support Emerging Innovative Actors in Organic Agriculture: The Case of Participatory Plant Breeding in Europe. Org. Farming 2017, 3, 20-33. [CrossRef]

39. Warner, K.D. Extending Agroecology: Grower Participation in Partnerships Is Key to Social Learning. Renew. Agric. Food Syst. 2006, 21, 84-94. [CrossRef]

40. McKitterick, L.; Quinn, B.; McAdam, R.; Dunn, A. Innovation Networks and the Institutional Actor-Producer Relationship in Rural Areas: The Context of Artisan Food Production. J. Rural Stud. 2016, 48, 41-52. [CrossRef]

41. Ingram, J. Are Farmers in England Equipped to Meet the Knowledge Challenge of Sustainable Soil Management? An Analysis of Farmer and Advisor Views. J. Environ. Manag. 2008, 86, 214-228. [CrossRef]

42. Lehébel-Péron, A.; Sidawy, P.; Dounias, E.; Schatz, B. Attuning Local and Scientific Knowledge in the Context of Global Change: The Case of Heather Honey Production in Southern France. J. Rural Stud. 2016, 44, 132-142. [CrossRef]

43. Šūmane, S.; Kunda, I.; Knickel, K.; Strauss, A.; Tisenkopfs, T.; des los Rios, I.; Rivera, M.; Chebach, T.; Ashkenazy, A. Local and Farmers' Knowledge Matters! How Integrating Informal and Formal Knowledge Enhances Sustainable and Resilient Agriculture. J. Rural Stud. 2018, 59, 232-241. [CrossRef]

44. Bocci, R.; Rey, F.; Chable, V. Policy Recommendations to Sustain Diversity Strategies within Food Systems. SOLIBAM Proj. 2014. Available online: www.solibam.eu (accessed on 28 December 2021).

45. Moschitz, H.; Roep, D.; Brunori, G.; Tisenkopfs, T. Learning and Innovation Networks for Sustainable Agriculture: Processes of Co-Evolution, Joint Reflection and Facilitation. J. Agric. Educ. Ext. 2015, 21, 1-11. [CrossRef]

46. Wood, B.; Blair, H.T.; Gray, D.I.; Kemp, P.D.; Kenyon, P.R.; Morris, S.T.; Sewell, A. Agricultural Science in the Wild: A Social Network Analysis of Farmer Knowledge Exchange. PLoS ONE 2014, 9, e105203. [CrossRef] [PubMed]

47. EU SCAR AKIS. Preparing for Future AKIS in Europe; European Commission: Brussels, Belgium, 2019.

48. Goulet, F. Narratives of Experience and Production of Knowledge within Farmers' Groups. J. Rural Stud. 2013, 32, 439-447. [CrossRef]

49. Le Hénaff, D.; Cebeci, Z. Agroecology for Farmers: The Linguistic Issue. In Sustainable Agriculture Reviews 14: Agroecology and Global Change; Ozier-Lafontaine, H., Lesueur-Jannoyer, M., Eds.; Springer International Publishing: Cham, Switzerland, 2014; pp. 331-343. ISBN 978-3-319-06016-3. 
50. Bliss, K.; Padel, S.; Cullen, B.; Ducottet, C.; Mullender, S.; Rasmussen, I.A.; Moeskops, B. Exchanging Knowledge to Improve Organic Arable Farming: An Evaluation of Knowledge Exchange Tools with Farmer Groups across Europe. Org. Agric. 2019, 9 , 383-398. [CrossRef]

51. Kaup, B.Z. The Reflexive Producer: The Influence of Farmer Knowledge Upon the Use of Bt Corn. Rural Sociol. $2008,73,62-81$. [CrossRef]

52. Mills, J.; Gibbon, D.; Ingram, J.; Reed, M.; Short, C.; Dwyer, J. Organising Collective Action for Effective Environmental Management and Social Learning in Wales. J. Agric. Educ. Ext. 2011, 17, 69-83. [CrossRef]

53. Pardede, J.; Sitohang, B.; Akbar, S.; Khodra, M.L. Implementation of Transfer Learning Using VGG16 on Fruit Ripeness Detection. Int. J. Intell. Syst. Appl. 2021, 13, 52-61. [CrossRef]

54. Curry, N.; Ingram, J.; Kirwan, J.; Maye, D. Knowledge Networks for Sustainable Agriculture in England. Outlook Agric. 2012, 41, 243-248. [CrossRef]

55. Crawford, C.; Grossman, J.; Warren, S.T.; Cubbage, F. Grower Communication Networks: Information Sources for Organic Farmers. J. Ext. 2015, 53, 3FEA9.

56. Sagor, E.S.; Becker, D.R. Personal Networks and Private Forestry in Minnesota. J. Environ. Manag. 2014, 132, 145-154. [CrossRef] [PubMed]

57. Klerkx, L.; Proctor, A. Beyond Fragmentation and Disconnect: Networks for Knowledge Exchange in the English Land Management Advisory System. Land Use Policy 2013, 30, 13-24. [CrossRef]

58. Ortolani, L.; Micheloni, C. Identification of the Best Methods for Learning and Knowledge Exchange. D 3.2 of OK-Net Arable; AIAB: Rome, Italy, 2016.

59. Butler, A.; Lobley, M. Resource Management, Knowledge and Internet Use on Farms in SouthWest England: A Report for the SWARM Knowledge Hub; Centre for Rural Policy Research, University of Exeter: Exeter, UK, 2012.

60. Eurostat Organic Farming Statistics. 2021. Available online: https://ec.europa.eu/eurostat/statistics-explained/index.php?title= Organic_farming_statistics\&oldid=554979 (accessed on 28 December 2021).

61. Läpple, D.; Rensburg, T.V. Adoption of Organic Farming: Are There Differences between Early and Late Adoption? Ecol. Econ. 2011, 70, 1406-1414. [CrossRef]

62. Godfray, H.C.J.; Beddington, J.R.; Crute, I.R.; Haddad, L.; Lawrence, D.; Muir, J.F.; Pretty, J.; Robinson, S.; Thomas, S.M.; Toulmin, C. Food Security: The Challenge of Feeding 9 Billion People. Science 2010, 327, 812-818. [CrossRef]

63. Spaapen, J.B. A New Evaluation Culture Is Inevitable. Org. Farming 2015, 1, 36-37. [CrossRef]

64. Kania, J.; Vinohradnik, K.; Tworzyk, A. Advisory Services in System of Agricultural Knowledge and Information in Poland. In Proceedings of the 11th European IFSA Symposium, Berlin, Germany, 1-4 April 2014; pp. 120-130.

65. EU SCAR. Agricultural Knowledge and Innovation Systems towards 2020-An Orientation Paper on Linking Innovation and Research; European Commission: Brussels, Belgium, 2013.

66. Darnhofer, I.; Lindenthal, T.; Bartel-Kratochvil, R.; Zollitsch, W. Conventionalisation of Organic Farming Practices: From Structural Criteria towards an Assessment Based on Organic Principles. A Review. Agron. Sustain. Dev. 2010, 30, 67-81. [CrossRef]

67. Ratnadass, A.; Fernandes, P.; Avelino, J.; Habib, R. Plant Species Diversity for Sustainable Management of Crop Pests and Diseases in Agroecosystems: A Review. Agron. Sustain. Dev. 2012, 32, 273-303. [CrossRef]

68. Granatstein, D.; Andrews, P.; Groff, A. Productivity, Economics, and Fruit and Soil Quality of Weed Management Systems in Commercial Organic Orchards in Washington State, USA. Org. Agric. 2014, 4, 197-207. [CrossRef]

69. Scherr, S.J.; McNeely, J.A. Biodiversity Conservation and Agricultural Sustainability: Towards a New Paradigm of 'Ecoagriculture' Landscapes. Philos. Trans. R. Soc. B Biol. Sci. 2008, 363, 477-494. [CrossRef]

70. Rahmann, G.; Reza Ardakani, M.; Bàrberi, P.; Boehm, H.; Canali, S.; Chander, M.; David, W.; Dengel, L.; Erisman, J.W.; Galvis-Martinez, A.C.; et al. Organic Agriculture 3.0 Is Innovation with Research. Org. Agric. 2017, 7, 169-197. [CrossRef]

71. Hermans, F.; Klerkx, L.W.A.; Roep, D. Structural Conditions for Dynamic Innovation Networks: A Review of Eight European Agricultural Knowledge and Innovation Systems. In Proceedings of the 10th European IFSA Symposium, Aarhus, Denmark, 1-4 July 2012; pp. 1-11.

72. IFOAM Principles of Organic Agriculture. Preamble; IFOAM Organic International: Bonn, Germany, 2017; Available online: https:/ / www.ifoam.bio/principles-organic-agriculture-brochure (accessed on 28 December 2021). 